\title{
CTSZ Gene
}

National Cancer Institute

\section{Source}

National Cancer Institute. CTSZ Gene. NCI Thesaurus. Code C24320.

This gene plays a role in intracellular protein catabolism. 